\title{
Electrolyte-Labile Increase of Oxygen Affinity during In Vivo Aging of Hemoglobin*
}

\author{
Miles J. Edwards $\ddagger$ and Demetrios A. Rigas \\ (From the Department of Medicine, Division of Chest Diseases and Division of Experimental \\ Medicine, University of Oregon Medical School, Portland, Oregon)
}

\begin{abstract}
Normal human erythrocytes were separated according to in vivo age by ultracentrifugation. The "young" and "old" erythrocytes had mean cell ages of approximately 40 and 79 days, respectively. "Young" erythrocytes had a lower oxygen affinity and a higher heme-heme interaction than did "old" erythrocytes. This indicates an impairment of the oxygen-carrying function of erythrocyte hemoglobin with age.

"Young" and "old" erythrocytes were hemolyzed yielding "young" and "old" hemoglobins. "Young" hemoglobin had a comparably lower oxygen affinity than did "old" hemoglobin when the hemolysates were dialyzed against electrolyte-free water.

Exposure to sodium chloride completely obliterated this difference between the oxygen affinities and buffer values of "young" and "old" free hemoglobin. Similar exposure to potassium chloride resulted in partial obliteration of the difference between the oxygen affinities of "young" and "old" hemoglobin. Subsequent removal of sodium chloride by dialysis did not restore the preelectrolyte differences between the oxygen affinities of "young" and "old" hemoglobin.

This evidence indicates that in vivo aging is accompanied by a conformational change of the hemoglobin molecule, which is probably due to an alteration of electrostatic interactions involving the hemoglobin molecule and which is retained after hemolysis and dialysis against water but is obliterated by addition of electrolyte. It is not possible, however, to decide from the available evidence whether this molecular change occurs independently or as a result of influences by other substances, such as 2,3-diphosphoglycerate, which also change during in vivo aging of the erythrocyte.
\end{abstract}

\section{Introduction}

The normal human erythrocyte undergoes extensive structural, chemical, and metabolic change during its normal aging within the circulation

* Received for publication 3 April 1967 and in revised form 12 June 1967.

This work was supported in part by research grant AM 05012 from the National Institutes of Health, by the Oregon Heart Association, by the Cardiovascular Program Project Grant HE-06336 and by the U. S. Atomic Energy Commission, Contract AT (45-1)-581.

Presented in part before a joint meeting of the Western Section, American Federation for Clinical Research and the Western Society for Clinical Research, 28 January 1967, Carmel, Calif.
(1-3). Among other changes, the erythrocyte loses its nucleus, ribosomes, and messenger RNA early in its life and thus loses its ability to synthesize new proteins to replace any aging, i.e., deteriorating, molecules of hemoglobin and enzymes. It, therefore, provides a unique opportunity to study aging of individual protein components without new synthesis obscuring the findings.

In earlier work, we established that in vivo aging of erythrocytes is accompanied by a small in-

$\ddagger$ Address requests for reprints to Miles J. Edwards, M. D., Department of Medicine, Division of Chest Diseases, University of Oregon Medical School, 3181 S. W. Sam Jackson Park Road, Portland, Oreg. 97201. 
crease in oxygen affinity which was attributed to a change of "macromolecules" within the erythrocyte, probably of hemoglobin itself (4). In the present work, using improved techniques, we show that this increase of oxygen affinity with in vivo aging is considerably larger and is associated with a decrease in the interaction of hemes in determining the extent to which each heme can release oxygen. There is a comparable difference in oxygen affinity between deionized hemolysates prepared from young and old erythrocytes. This difference is abolished by the addition of electrolytes, suggesting that electrostatic forces are important in maintaining a subtle change with age in the conformation of the hemoglobin molecule.

\section{Methods}

Heparinized venous blood was obtained from normal young adults. The buffy coat was removed after $30 \mathrm{~min}$ centrifugation at $2000 \mathrm{rpm}$ at $4^{\circ} \mathrm{C}$. The packed erythrocytes were again suspended in plasma. Ultracentrifugation for $1 \mathrm{hr}$ at $67,000 \mathrm{~g}$ at the tip $(22,500 \mathrm{rpm}$, radius $11.9 \mathrm{~cm}$ ) was then carried out at $4^{\circ} \mathrm{C}$. This is an accepted technique for separating erythrocytes of differing mean cell ages $(5,6)$. The top layer, representing approximately $15 \%$ of the packed erythrocyte volume, was separated and designated as "young" erythrocytes. Similarly, the bottom layer, representing approximately $15 \%$ of the packed erythrocyte volume, was separated and designated as "old" erythrocytes.

Preparation of erythrocyte suspensions. The separated "young" and "old" erythrocytes were washed three times in autologous plasma to remove any free hemoglobin due to minimal hemolysis that may have occurred during the procedure. Each sample was then suspended in sufficient plasma, containing sodium fluoride as an inhibitor of glycolysis, to bring the final hemoglobin concentration of the erythrocyte suspension to $4.0 \mathrm{~g} / 100 \mathrm{ml}$.

Preparation of hemoglobin solutions. The separated "young" and "old" erythrocytes were washed three times with isotonic saline to remove free hemoglobin and plasma proteins. The hemoglobin was then liberated by osmotic hemolysis with water and toluene followed by centrifugation to clarify the hemolysate (7). Hemoglobin solutions prepared from "young" and "old" erythrocytes are designated, respectively, as "young" and "old" hemoglobins. Each matched pair of "young" and "old" hemoglobin was subsequently dialyzed for approximately 18 hr at $4^{\circ} \mathrm{C}$ in one container against distilled water or a specified electrolyte solution. Sufficient dialysis fluid was later added to bring the final hemoglobin concentration of each sample to $4.0 \mathrm{~g} / 100 \mathrm{ml}$.

In one instance, deionization of the hemolysates was carried out by gel filtration through P-2 polyacrylamide gel. $4 \mathrm{ml}$ of hemolysate was located on a column of 0.9 $\mathrm{cm}$ internal diameter with a gel bed height of $37 \mathrm{~cm}$ that was equilibrated with distilled deionized water. The hemoglobin was eluted with distilled deionized water at a flow rate of $20 \mathrm{ml} / \mathrm{hr}$. The residual electrolyte in hemolysates after dialysis against electrolyte-free water or gel filtration was estimated from their conductivity using a Klett conductivity bridge. The results were expressed in terms of their molarity equivalent to that of potassium chloride giving the same conductivity.

Determination of oxygen-hemoglobin equilibria of erythrocyte suspensions and hemoglobin solutions. The oxygen-hemoglobin equilibria were determined by the mixing technique of Edwards and Martin (8) and the $\mathrm{pH}$ was measured according to the technique of SiggaardAndersen et al. (9) at $37^{\circ} \mathrm{C}$. For the purpose of comparing "young" and "old" hemoglobin solutions, we mixed equal volumes of prepared oxyhemoglobin and deoxyhemoglobin to produce a virtual $50 \%$ oxyhemoglobin saturation. Even with such a constant mix ratio of oxyhemoglobin and deoxyhemoglobin, there is a small variation in oxyhemoglobin saturation because solutions of great oxygen affinity bind more oxygen as oxyhemoglobin, leaving less oxygen in physical solution. The variation in oxyhemoglobin is not great and is totally dependent upon the variable in question, oxygen affinity. The oxygen pressure was then measured at $37^{\circ} \mathrm{C}$ and will be designated as $P_{50}(8)$. The $P_{50}$ is inversely related to the oxygen affinity. "Young" and "old" hemoglobin solutions were not buffered to control $\mathrm{pH}$. Instead, under the acidifying influence of carbon dioxide at a partial pressure of $40 \mathrm{~mm} \mathrm{Hg}$, the $\mathrm{pH}$ was allowed to vary as the respective buffer properties of the "young" and "old" hemoglobins permitted. Without the obvious disadvantage of an electrolyte buffer, carbon dioxide provided a sufficiently acid $\mathrm{pH}$ to decrease the oxygen affinities of "young" and "old" hemoglobins to approximately those of "young" and "old" erythrocytes. This facilitated comparisons of "young" and "old" hemoglobins under the strikingly different situations of intracellular crowding (10) and extracellular dispersion.

Determination of statistical significance. We used Student's $t$ test to determine the significance of differences between groups. We chose a $P$ value of $<0.01$ as being clearly significant.

\section{Results}

The results of the studies of "young" and "old" intact erythrocytes are listed in Table I, corrected to a plasma $\mathrm{pH}$ of $7.40(11)$ at $37^{\circ} \mathrm{C}$. The mean oxygen-hemoglobin equilibrium curve for "young" and "old" intact erythrocytes is shown in Fig. 1. The oxygen-hemoglobin equilibrium curve of "old" erythrocytes is almost identical with that of unseparated normal erythrocytes of human whole blood $(8,12)$. The "young" erythrocytes had greater partial pressures of oxygen than did "old" erythrocytes at all oxyhemoglobin saturations studied and were proven to be statistically significant 
TABLE I

Oxygen-hemoglobin equilibria of normal "young" and "old" erythrocytes suspended in plasma containing sodium fluoride, corrected to a plasma $\mathrm{pH}$ of 7.40

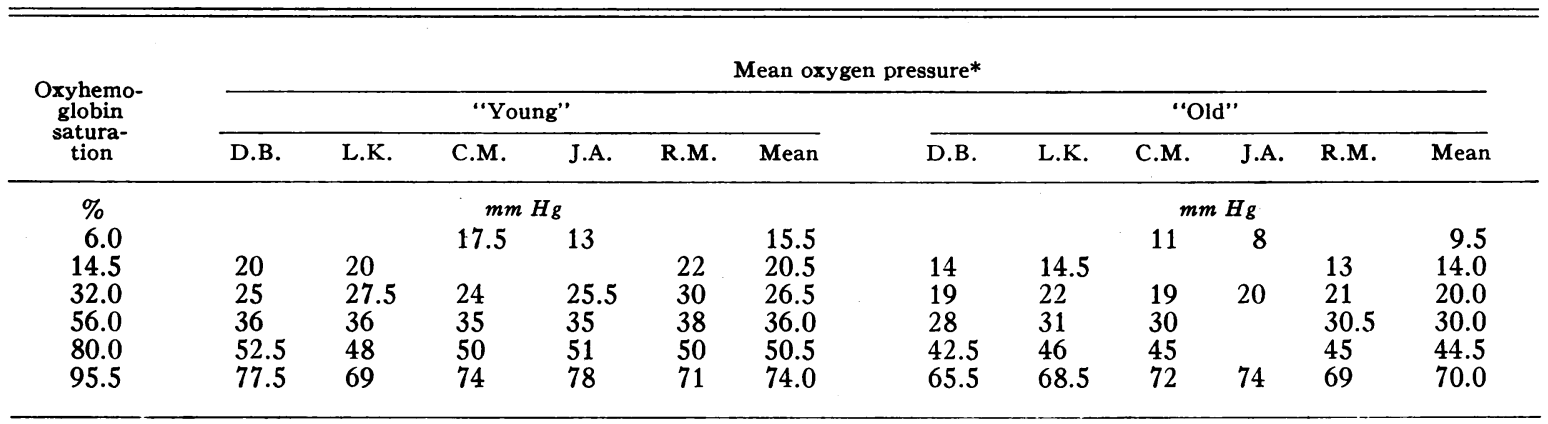

* Corrected to a plasma $\mathrm{pH}$ of 7.40.

D.B., L.K., C.M., J.A., and R.M. are initials of blood donors.

at both 32.0 and $56.0 \%$ saturation $(P<0.001)$. In its normal movement from a nearly normal arterial oxygen pressure of $75 \mathrm{~mm} \mathrm{Hg}$ to a typical mixed venous oxygen pressure of $40 \mathrm{~mm} \mathrm{Hg}$ (disregarding influence of carbon dioxide exchange), the "old" erythrocyte yields oxygen to the metabolizing tissues in amounts of $22.5 \%$ of its oxygen capacity whereas the "young" erythrocyte yields
$30.5 \%$ of its oxygen capacity (see Fig. 1). "Young" erthyrocytes had greater heme-heme interaction than did "old" erythrocytes $(P<0.005)$ according to Hill's equation for " $n$ " (13) (see Table II).

Comparisons of $\mathrm{P}_{50}$ and $\mathrm{pH}$ of "young" and "old" hemoglobin solutions were made in electrolyte-free water and in various concentrations of

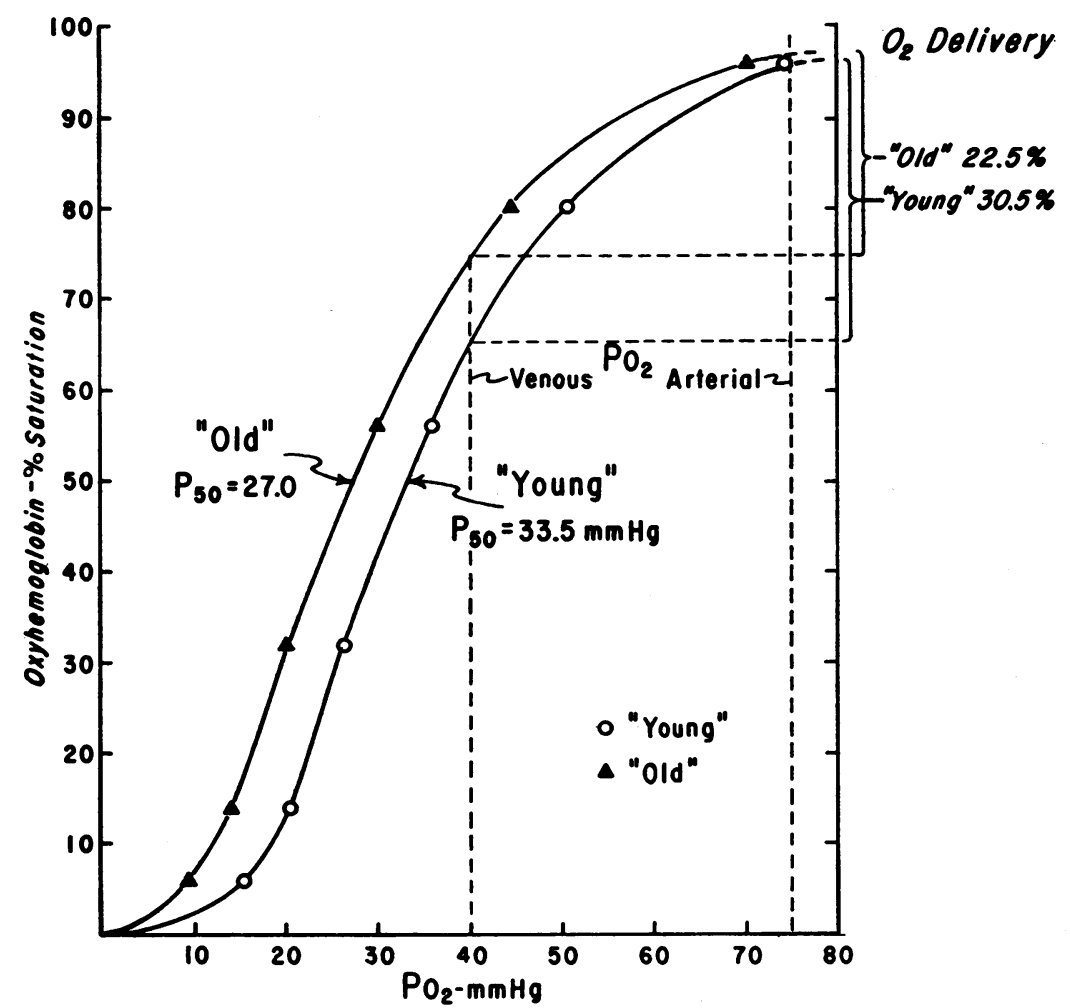

Fig. 1. Normal human "young" and "old" erythrocytes in plasma with SODIUM FLUORIDE, CORRECTED TO $\mathrm{PH} 7.4$, AT $37^{\circ} \mathrm{C}$. 
TABLE II

Hill's " $n$ " values for intact "young" and "old" erythrocytes, calculated using the least squares methods, excluding data at $95.5 \%$ oxyhemoglobin saturation

\begin{tabular}{lcc}
\hline \hline Donor & "Young" & "Old" \\
\hline D.B. & 3.18 & 2.81 \\
L.K. & 3.61 & 2.75 \\
C.M. & 3.76 & 2.88 \\
R.M. & 3.87 & 2.55 \\
Mean & 3.61 & 2.75 \\
SD & 0.31 & 0.14
\end{tabular}

Hill's "n" $=\left(1 / \log \mathrm{Po}_{2}\right)[(\log Y / 1-Y)-\log K]$ where $\mathrm{Po}_{2}$ is oxygen pressure in $\mathrm{mm} \mathrm{Hg}, Y$ is oxyhemoglobin fractional saturation, and $K$ is a constant.

sodium and potassium chloride solution at a carbon dioxide pressure of $40 \mathrm{~mm} \mathrm{Hg}$ and $37^{\circ} \mathrm{C}$ (see Table III). "Young" hemoglobin had a significantly higher $\mathrm{P}_{50}$ than did "old" hemoglobin $(P<0.001)$ when both were dissolved in electrolyte-free water. Under these conditions, solutions of "young" hemoglobin were slightly less acid than those of "old" hemoglobin, which was significant when the $\mathrm{pH}$ values were considered as paired observations $(P<0.001)$. The $\mathrm{pH}$ difference was opposite in direction to that which would produce the difference in $\mathrm{P}_{50}$. When there was no environmental carbon dioxide, there was again a higher $\mathrm{P}_{50}$ but not a higher $\mathrm{pH}$ in "young" as compared to "old" electrolyte-free hemoglobin solutions (see Table IV). This observation indicates that the age-dependent differences in oxygen affinity are independent of carbamino effects and that there is an essentially equal dissociation of protons by "young" hemoglobin and "old" hemoglobin. Electrolyte-free "young" hemoglobin is then perhaps a more effective buffer against carbonic acid than is electrolyte-free "old" hemoglobin. The physiological relevance of this is uncertain, however, since we could not demonstrate a difference in the buffer capabilities of "young" and "old" intact erythrocytes (see Table V).

TABLE III

Oxygen pressures and pH of hemoglobin solutions ( $4 \mathrm{~g} / 100 \mathrm{ml})$ prepared from "young" and "old" normal human erythrocytes ( $50 \%$ oxyhemoglobin saturation, $\mathrm{PCO}_{2}=40 \mathrm{~mm} \mathrm{Hg}, 37^{\circ} \mathrm{C}$ ), after overnight dialysis $\left(4^{\circ} \mathrm{C}\right)$ in water with or without added electrolyte

\begin{tabular}{|c|c|c|c|c|c|c|c|c|c|c|}
\hline & \multicolumn{3}{|c|}{ No electrolyte } & \multicolumn{7}{|c|}{ Electrolyte } \\
\hline & \multirow[b]{2}{*}{ "Young" } & \multirow[b]{2}{*}{ “Old" } & \multirow[b]{2}{*}{ Diff. } & \multirow[b]{2}{*}{ Molarity } & \multicolumn{3}{|c|}{ Sodium chloride } & \multicolumn{3}{|c|}{ Potassium chloride } \\
\hline & & & & & "Young" & "Old" & Diff. & "Young" & "Old" & Diff. \\
\hline $\begin{array}{l}\mathrm{P}_{50} \\
\mathrm{pH}\end{array}$ & $\begin{array}{c}32 \\
(6.65)\end{array}$ & $\begin{array}{c}28 \\
(6.60)\end{array}$ & $\begin{array}{c}+4 \\
(+0.05)\end{array}$ & 0.15 & $\begin{array}{c}33 \\
(6.50)\end{array}$ & $\begin{array}{c}32 \\
(6.53)\end{array}$ & $\begin{array}{c}+1 \\
(-0.03)\end{array}$ & $\begin{array}{c}35 \\
(6.56)\end{array}$ & $\begin{array}{c}34 \\
(6.57)\end{array}$ & $\begin{array}{c}+1 \\
(-0.01)\end{array}$ \\
\hline $\begin{array}{l}\mathrm{P}_{50} \\
\mathrm{pH}\end{array}$ & $\begin{array}{c}31 \\
(6.66)\end{array}$ & $\begin{array}{c}23 \\
(6.62)\end{array}$ & $\begin{array}{c}+8 \\
(+0.04)\end{array}$ & 0.10 & $\begin{array}{c}34 \\
(6.60)\end{array}$ & $\begin{array}{c}34 \\
(6.60)\end{array}$ & $\begin{array}{l}0 \\
(0.00)\end{array}$ & $\begin{array}{c}36 \\
(6.60)^{-}\end{array}$ & $\begin{array}{c}31 \\
(6.59)\end{array}$ & $\begin{array}{c}+5 \\
(+0.01)\end{array}$ \\
\hline $\begin{array}{l}\mathrm{P}_{50} \\
\mathrm{pH}\end{array}$ & $\begin{array}{c}34 \\
(6.61)\end{array}$ & $\begin{array}{c}22 \\
(6.57)\end{array}$ & $\begin{array}{r}+12 \\
(+0.04)\end{array}$ & 0.10 & $\begin{array}{c}30 \\
(6.68)\end{array}$ & $\begin{array}{c}30 \\
(6.67)\end{array}$ & $\begin{array}{c}0 \\
(+0.01)\end{array}$ & $\begin{array}{c}38 \\
(6.61)\end{array}$ & $\begin{array}{c}34 \\
(6.61)\end{array}$ & $\begin{array}{c}+4 \\
(0.00)\end{array}$ \\
\hline $\begin{array}{l}\mathrm{P}_{50} \\
\mathrm{pH}\end{array}$ & $\begin{array}{c}38 \\
(6.58)\end{array}$ & $\begin{array}{c}27 \\
(6.54)\end{array}$ & $\begin{array}{c}+11 \\
(+0.04)\end{array}$ & 0.08 & & & & $\begin{array}{c}36 \\
(6.59)\end{array}$ & $\begin{array}{c}32 \\
(6.59)\end{array}$ & $\begin{array}{l}+4 \\
(0.00)\end{array}$ \\
\hline $\begin{array}{l}\mathrm{P}_{50} \\
\mathrm{pH}\end{array}$ & $\begin{array}{c}35 \\
(6.57)\end{array}$ & $\begin{array}{c}23 \\
(6.56)\end{array}$ & $\begin{array}{c}+12 \\
(+0.01)\end{array}$ & 0.02 & & & & $\begin{array}{c}30 \\
(6.60)\end{array}$ & $\begin{array}{c}26 \\
(6.60)\end{array}$ & $\begin{array}{l}+4 \\
(0.00)\end{array}$ \\
\hline $\begin{array}{l}\mathrm{P}_{50} \\
\mathrm{pH}\end{array}$ & $\begin{array}{c}36 \\
(6.55)\end{array}$ & $\begin{array}{c}27 \\
(6.52)\end{array}$ & $\begin{array}{c}+9 \\
(+0.03)\end{array}$ & 0.01 & $\begin{array}{c}31 \\
(6.61)\end{array}$ & $\begin{array}{c}30 \\
(6.58)\end{array}$ & $\begin{array}{c}+1 \\
(+0.03)\end{array}$ & $\begin{array}{c}32 \\
(6.62)\end{array}$ & $\begin{array}{c}30 \\
(6.60)\end{array}$ & $\begin{array}{c}+2 \\
(+0.02)\end{array}$ \\
\hline $\begin{array}{l}\mathrm{P}_{50} \\
\mathrm{pH}\end{array}$ & $\begin{array}{c}36 \\
(6.58)\end{array}$ & $\begin{array}{c}30 \\
(6.55)\end{array}$ & $\begin{array}{c}+6 \\
(+0.03)\end{array}$ & 0.01 & $\begin{array}{c}34 \\
(6.58)\end{array}$ & $\begin{array}{c}34 \\
(6.59)\end{array}$ & $\begin{array}{c}0 \\
(-0.01)\end{array}$ & & & \\
\hline$\stackrel{\mathrm{P}_{50}}{\mathrm{pH}}$ & $\begin{array}{c}37 \\
(6.61)\end{array}$ & $\begin{array}{c}30 \\
(6.57)\end{array}$ & $\begin{array}{c}+7 \\
(+0.04)\end{array}$ & & & & & & & \\
\hline $\begin{array}{l}\text { Means } \\
\text { P }_{50} \\
\text { SD } \\
\text { pH } \\
\text { SD }\end{array}$ & $\begin{array}{c}34.9 \\
2.4 \\
(6.60) \\
(0.04)\end{array}$ & $\begin{array}{c}26.2 \\
3.2 \\
(6.57) \\
(0.03)\end{array}$ & $\begin{array}{c}+8.6 \\
2.9 \\
(+0.035) \\
(0.01)\end{array}$ & . & $\begin{array}{c}32.4 \\
1.8 \\
(6.59) \\
(0.06)\end{array}$ & $\begin{array}{c}32.0 \\
2.0 \\
(6.59) \\
(0.05)\end{array}$ & $\begin{array}{c}+0.4 \\
0.5 \\
(0.00) \\
(0.02)\end{array}$ & $\begin{array}{l}34.5 \\
2.9 \\
(6.60) \\
(0.02)\end{array}$ & $\begin{array}{l}31.2 \\
3.0 \\
(6.59) \\
(0.01)\end{array}$ & $\begin{array}{c}+3.3 \\
1.5 \\
(0.00) \\
(0.01)\end{array}$ \\
\hline
\end{tabular}

$\mathrm{P}_{50}$, Partial pressure of oxygen in $\mathrm{mm} \mathrm{Hg}$ at $50 \%$ oxyhemoglobin saturation; Diff., Difference, "young" minus "old"; $\mathrm{PCO}_{2}$, partial pressure of carbon dioxide. 
TABLE IV

Oxygen pressures and $p H$ of hemoglobin solutions $(4.0 \mathrm{~g} / 100 \mathrm{ml})$ prepared from "young" and "old" normal human erythrocytes $\left(50 \%\right.$ oxyhemoglobin saturation, $\left.37^{\circ} \mathrm{C}\right)$, after overnight dialysis $\left(4^{\circ} \mathrm{C}\right)$ in water without electrolyte

Carbon dioxide is not present in the equilibrating gas.

\begin{tabular}{lllll}
\hline \hline & Donor & "Young" & “Old" & Diff. \\
\hline I. Oxygen pressure & D.B. & 20 & 14 & +6 \\
& D.D. & 17 & 12 & +5 \\
& Mean & 18.5 & 13.0 & +5.5 \\
II. pH & C.S. & 7.20 & 7.15 & +0.05 \\
& J.U. & 7.23 & 7.19 & +0.04 \\
& I.J. & 7.20 & 7.24 & -0.04 \\
& C.W. & 7.19 & 7.15 & +0.04 \\
& G.N. & 6.94 & 7.06 & -0.12 \\
& T.C. & 7.00 & 7.08 & -0.08 \\
& D.W. & 7.04 & 7.06 & -0.02 \\
& Mean & 7.11 & 7.13 & -0.02
\end{tabular}

Diff., difference, "young" minus "old."

We investigated the possibility that the "young" - "old" difference in $P_{50}$ is actually the result of difference in residual electrolyte concentration because of incomplete dialysis. We determined the conductivity of desalted hemolysates either by the usual dialysis against electrolyte-free water for 18 $\mathrm{hr}$ or by gel filtration through polyacrylamide gel P-2. The equivalent molarity of potassium chloride giving conductivity equal to the hemolysate was then calculated and is listed in Table VI along with the determined $\mathrm{P}_{50}$ for these "young" and "old" hemoglobins. Only minute amounts of electrolyte were retained although in each of these two comparisons there was slightly more electrolyte in the solution of "young" hemoglobin than in that of "old" hemoglobin.

TABLE $\mathrm{V}$

Change in plasma $p H$ produced by varying the carbon dioxide pressure between 21 and $84 \mathrm{~mm} \mathrm{Hg}$ in plasma suspensions (with added sodium fluoride) of "young" and "old" normal human erythrocytes at $100 \%$ oxyhemoglobin saturation, $15 \mathrm{~g} / 100 \mathrm{ml}$ of hemoglobin at $37^{\circ} \mathrm{C}$

\begin{tabular}{lccccccc}
\hline & \multicolumn{3}{c}{ "Young" } & & \multicolumn{3}{c}{ "Old" } \\
\cline { 2 - 4 } \cline { 6 - 8 } Donor & $\mathbf{2 1}$ & $\mathbf{8 4}$ & Change & & $\mathbf{2 1}$ & $\mathbf{8 4}$ & Change \\
\hline C.M. & 7.56 & 7.16 & $\mathbf{0 . 4 0}$ & & 7.54 & 7.16 & 0.38 \\
D.B. & 7.52 & 7.18 & 0.34 & & 7.55 & 7.19 & 0.34 \\
B.B. & 7.61 & 7.23 & 0.38 & & 7.61 & 7.22 & 0.39 \\
Mean change & & 0.37 & & & 0.37 \\
\hline
\end{tabular}

21, plasma $\mathrm{pH}$ at a carbon dioxide pressure of $21 \mathrm{~mm} \mathrm{Hg}$; 84 , plasma $\mathrm{pH}$ at a carbon dioxide pressure of $84 \mathrm{~mm} \mathrm{Hg}$; Change, difference in plasma $\mathrm{pH}$ between carbon dioxide pressures of 21 and $84 \mathrm{~mm} \mathrm{Hg}$.
TABLE VI

Conductivity and calculated electrolyte molarity of hemoglobin solutions (4 $\mathrm{g} / 100 \mathrm{ml}$ ) prepared from "young" and "old" normal human erythrocytes after attempts at complete electrolyte removal and their oxygen pressures at $50 \%$ oxyhemoglobin saturation, $\mathrm{PCO}_{2}=40 \mathrm{~mm} \mathrm{Hg}$ at $37^{\circ} \mathrm{C}$

\begin{tabular}{llllll}
\hline \hline & \multicolumn{2}{c}{ Dialysis 18 hr } & & \multicolumn{2}{c}{ Gel filtration } \\
\cline { 2 - 3 } \cline { 5 - 6 } & "Young" & "Old" & "Young" & "Old" \\
\hline $\begin{array}{c}\text { Conductivity } \\
\text { (mhos X 10-5) }\end{array}$ & 11.4 & 7.9 & 14.2 & 7.0 \\
$\begin{array}{c}\text { Electrolyte } \\
\text { molarity } \\
\quad(\text { equivalent } \\
\text { to KCl) }\end{array}$ & 0.0014 & 0.0010 & 0.0018 & 0.0009 \\
$\mathrm{P}_{50}(\mathrm{~mm} \mathrm{Hg})$ & 33 & 26 & 39 & 30
\end{tabular}

Dialysis $18 \mathrm{hr}$, hemoglobin solutions dialyzed for $18 \mathrm{hr}$ at $4^{\circ} \mathrm{C}$ in distilled water without added electrolyte; gel filtration, hemoglobin solutions subjected to gel filtration through polyacrylamide gel $\mathrm{P}-2 ; \mathrm{P}_{50}$, partial pressure of oxygen in $\mathrm{mm} \mathrm{Hg}$ at $50 \%$ oxyhemoglobin saturation.

We were unable to detect the presence of measurable methemoglobin in dialyzed hemolysates using spectrophotometry and determination of inactive hemoglobin in either this or our previous study (4).

In potassium chloride solutions, the "young" hemoglobin had a much less marked but still significantly higher $\mathrm{P}_{50}$ than "old" hemoglobin when considered as paired studies $(P<0.001)$ but they had the same $\mathrm{pH}$. In sodium chloride solutions of greater than $0.01 \mathrm{~m}$ concentration, "young" and "old" hemoglobin solutions had the same $\mathrm{P}_{50}$ and $\mathrm{pH}$. Sodium chloride concentrations of less than 0.008 mole/liter were unable to obliterate "young" - "old" differences in $\mathrm{P}_{50}$ and $\mathrm{pH}$ (see Table VII). More complete descriptions of the oxygen-

TABLE VII

Oxygen pressures and $p H$ of hemoglobin solutions $(4 \mathrm{~g} / 100 \mathrm{ml})$ prepared from "young" and "old" normal human erythrocytes

(50\% oxyhemoglobin saturation, $\mathrm{PCO}_{2}=40 \mathrm{~mm} \mathrm{Hg}$, $37^{\circ} \mathrm{C}$ ) after $18 \mathrm{hr}$ dialysis $\left(4^{\circ} \mathrm{C}\right)$ in water containing small amounts of sodium chloride

\begin{tabular}{ccccc}
\hline \hline \multicolumn{2}{c}{ Molarity } & "Young" & “Old" & Diff. \\
\hline \multirow{2}{*}{0.008} & $\mathrm{P}_{50}$ & 22 & 17 & +5 \\
& $\mathrm{pH}$ & $(6.70)$ & $(6.70)$ & $(0.00)$ \\
0.008 & $\mathrm{P}_{50}$ & 34 & 27 & +7 \\
& $\mathrm{pH}$ & $(6.60)$ & $(6.58)$ & $(+0.02)$ \\
0.005 & $\mathrm{P}_{50}$ & 36 & 31 & +5 \\
& $\mathrm{pH}$ & $(6.68)$ & $(6.64)$ & $(+0.04)$
\end{tabular}

$\mathrm{PCO}_{2}$, partial pressure of carbon dioxide; $\mathrm{P}_{50}$, partial pressure of oxygen in $\mathrm{mm} \mathrm{Hg}$ at $50 \%$ oxyhemoglobin saturation; Diff., difference, "young" minus "old." 
hemoglobin equilibrium curves of a limited number of electrolyte-free and electrolyte-exposed hemoglobin solutions are shown in Figs. 2 and 3.

Comparisons of the differences between "young" and "old" hemoglobins exposed to differing electrolyte environments were also made. The "young" - "old" difference in $\mathrm{P}_{50}$ was significantly greater in electrolyte-free water than in either potassium chloride $(P<0.005)$ or sodium chloride $(P<0.001)$. The "young" - "old" difference in $\mathrm{P}_{50}$ was significantly greater in potassium chloride than in sodium chloride $(P<$ $0.005)$. The "young" - "old" difference in $\mathrm{pH}$ (carbon dioxide pressure $=40 \mathrm{~mm} \mathrm{Hg}$ ) was greater in electrolyte-free water than in potassium chloride $(P<0.001)$ or sodium chloride $(P<0.005)$.

Certain "young" and "old" hemoglobin samples were dialyzed for approximately $18 \mathrm{hr}$ in a specified concentration of an electrolyte and then returned to an electrolyte-free dialysis fluid for 24$48 \mathrm{hr}$, all at $4^{\circ} \mathrm{C}$. (Dialysis bags containing a total of about $20 \mathrm{ml}$ hemolysate were dialyzed

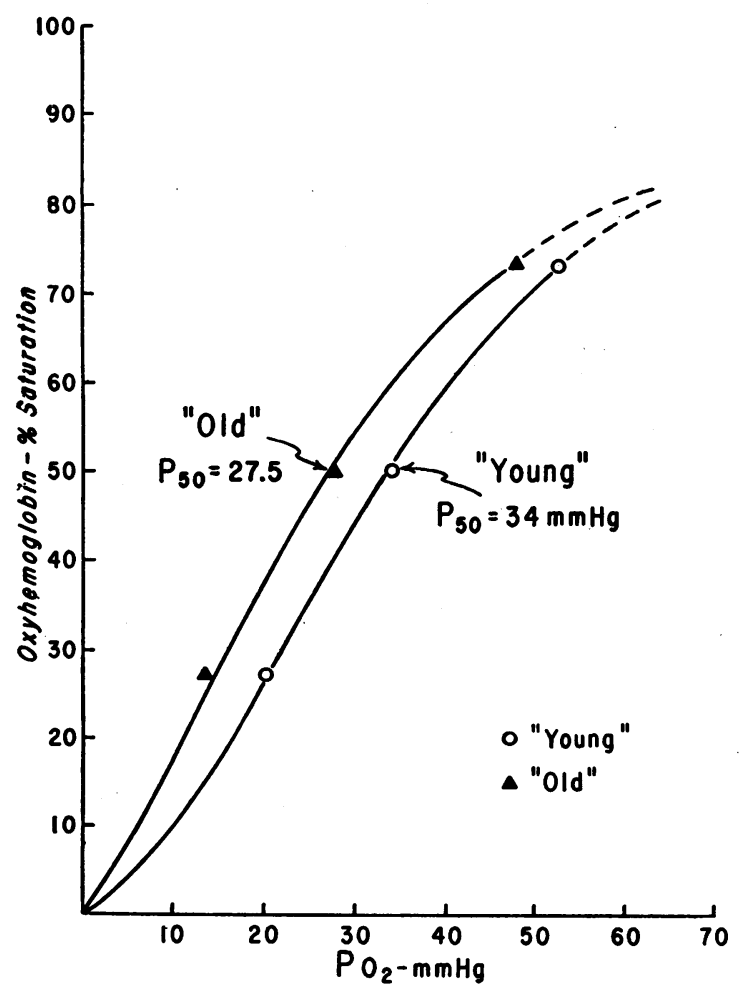

Fig. 2. Normal human "Young" and "Old" hemogloBIN IN DISTILLED WATER AT $37^{\circ} \mathrm{C}$.

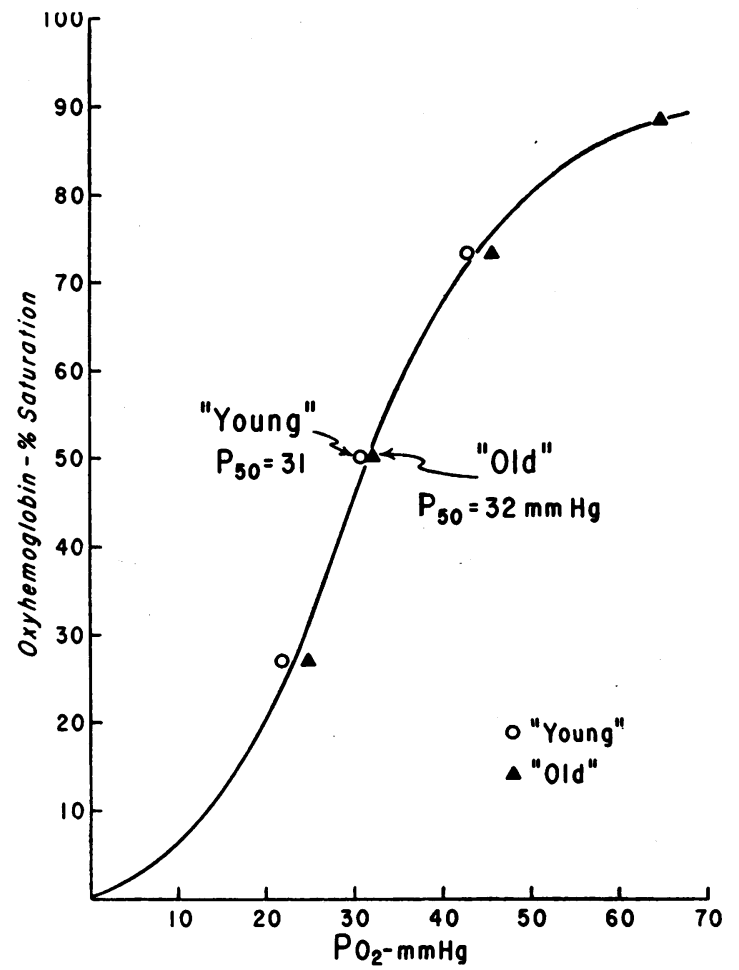

Fig. 3. Normal human "young" and “Old" hemogloBIN IN $0.2 \mathrm{M}$ PHOSPhATE BUFFER, PH 6.7 , at $37^{\circ} \mathrm{C}$.

against $6000 \mathrm{ml}$ of electrolyte-free distilled water which was changed once and continuously stirred.) The $\mathrm{P}_{50}$ and $\mathrm{pH}$ values are listed in Table VIII. Removal of dialyzable sodium and potassium chloride caused a dramatic decrease of $\mathrm{P}_{50}$ of both "young" and "old" hemoglobins. This is a separate in vitro phenomenon unrelated to in vivo aging and is described in detail elsewhere. ${ }^{1} \mathrm{Re}-$ moval of dialyzable sodium, however, did not restore "young" - "old" differences and they remained significantly less than those from samples exposed only to electrolyte-free water $(P<$ 0.001 ). Removal of dialyzable potassium was associated with a persisting "young" - "old" hemoglobin $\mathrm{P}_{50}$ and buffering ability difference, provided the initial potassium exposure was limited to $18 \mathrm{hr}$ and not extended to $48 \mathrm{hr}$. This finding suggests that potassium differs from sodium only in that it equalized these functions of "young" and "old" hemoglobin at a slower rate.

1 Walters, C., and M. J. Edwards. Subtle alteration of free hemoglobin by electrolytes: Permanent change of oxygen affinity. Submitted for publication. 
TABLE VIII

\begin{tabular}{|c|c|c|c|c|c|}
\hline Donor & Dialysis history & & "Young" & "Old" & Diff. \\
\hline D.B. & $\begin{array}{l}18 \mathrm{hr} 0.15 \mathrm{M} \mathrm{NaCl} \\
24 \mathrm{hr} \text { water }\end{array}$ & $\begin{array}{l}\text { (1) } \mathrm{P}_{50} \\
\text { (2) } \mathrm{pH}\end{array}$ & $\begin{array}{c}14 \\
(6.48)\end{array}$ & $\begin{array}{c}13 \\
(6.50)\end{array}$ & $\begin{array}{c}+1 \\
(-0.02)\end{array}$ \\
\hline T.U. & $\begin{array}{l}18 \mathrm{hr} 0.10 \mathrm{M} \mathrm{NaCl} \\
24 \mathrm{hr} \text { water }\end{array}$ & $\begin{array}{l}\text { (1) } \mathrm{P}_{50} \\
\text { (2) } \mathrm{pH}\end{array}$ & $\begin{array}{c}15 \\
(6.54)\end{array}$ & $\begin{array}{c}14 \\
(6.55)\end{array}$ & $\begin{array}{c}+1 \\
(-0.01)\end{array}$ \\
\hline T.C. & $\begin{array}{l}18 \mathrm{hr} 0.01 \mathrm{M} \mathrm{NaCl} \\
48 \mathrm{hr} \text { water }\end{array}$ & $\begin{array}{l}\text { (1) } \mathrm{P}_{50} \\
\text { (2) } \mathrm{pH}\end{array}$ & $\begin{array}{c}26 \\
(6.50)\end{array}$ & $\begin{array}{c}26 \\
(6.50)\end{array}$ & $\begin{array}{l}0 \\
(0.00)\end{array}$ \\
\hline C.C. & $\begin{array}{l}18 \mathrm{hr} 0.10 \mathrm{M} \mathrm{KCl} \\
48 \mathrm{hr} \text { water }\end{array}$ & $\begin{array}{l}\text { (1) } \mathrm{P}_{50} \\
\text { (2) } \mathrm{pH}\end{array}$ & $\begin{array}{c}22 \\
(6.59)\end{array}$ & $\begin{array}{c}11 \\
(6.52)\end{array}$ & $\begin{array}{c}+11 \\
(+0.07)\end{array}$ \\
\hline C.M. & $\begin{array}{l}48 \mathrm{hr} 0.10 \mathrm{M} \mathrm{KCl} \\
48 \mathrm{hr} \text { water }\end{array}$ & $\begin{array}{l}\text { (1) } \mathrm{P}_{50} \\
\text { (2) } \mathrm{pH}\end{array}$ & $\begin{array}{c}10 \\
(6.50)\end{array}$ & $\begin{array}{c}10 \\
(6.51)\end{array}$ & $\begin{array}{c}0 \\
(-0.01)\end{array}$ \\
\hline
\end{tabular}

$\mathrm{P}_{50}$, partial pressure of oxygen in $\mathrm{mm} \mathrm{Hg}$ at $50 \%$ oxyhemoglobin saturation ; Diff., difference, "young" minus "old"; $\mathrm{PCO}_{2}$, partial pressure of carbon dioxide; water, water free of electrolyte, large volume of which was changed at least twice during the dialysis period.

\section{Discussion}

Ultracentrifugation accomplishes separation only of relatively young from relatively old erythrocytes. According to the calculations of Garby and Hjelm (6), our "young" erythrocytes should have a mean cell age of about 40 days and our "old" erythrocytes should have a mean cell age of about 79 days. The "young" erythrocyte distribution curve, however, is skewed in such a way that the sample contains a large proportion of extremely young cells. By contrast, the "old" erythrocyte distribution is more balanced over a wide range and is old primarily in that it lacks an appreciable concentration of extremely young cells. Also, the "old" erythrocyte oxygen-hemoglobin equilibrium curve is almost identical with that of normal whole blood, which contains a normal complete spectrum of cell ages. This suggests that most of this functional change with age occurs in the extremely young cells. The changes with age determined here probably still fail to represent the complete magnitude of change occurring in the total approximate 120-day erythrocyte life-span.

The "young" intact erythrocyte contains hemoglobin which in its natural intracellular environment has a markedly improved ability to release oxygen at a wide range of venous oxygen pressures. Under normal physiological conditions, as the erythrocyte moves from artery to vein at oxygen pressures decreasing from 75 to $40 \mathrm{~mm} \mathrm{Hg}$, the "old" and "young" erythrocytes yield their oxygen to the metabolizing tissues in amounts of 22.5 and $30.5 \%$ saturation, respectively. This phenomenon is accompanied by and is probably the result of "young" hemoglobin's markedly increased heme-heme interaction which greatly decreases the affinity of a particular heme group for oxygen when the other heme groups in the molecule are already deoxygenated. The "young" erythrocyte, therefore, must be considered a functionally better cell which is destined to undergo a considerable functional deterioration with time in its natural in vivo environment.

Whatever has caused this functional change during in vivo aging is sufficiently stable to persist after the destruction of the cell, removal of membrane's lipid residue, and prolonged dialysis against electrolyte-free water. As previously described (14-16) and as illustrated in Figs. 2 and 3 , heme-heme interactions, indicated by the inflection of the oxygen-hemoglobin equilibrium curve, are greatly decreased in any ("young" or "old") electrolyte-free hemoglobin solution. Liberation of hemoglobin from the erythrocyte greatly increases its oxygen affinity. In our experimental procedure, however, the increased oxygen affinity resulting from liberation of hemoglobin is essentially counterbalanced by a decreased oxygen affinity due to acid $\mathrm{pH}$ produced by carbon dioxide, as limited by the buffering ability of hemoglobin. 
Despite these methodological considerations, the "young" - "old" differences in oxygen affinity of electrolyte-free hemoglobin solutions are comparable to those in the intracellular state. It is also noteworthy that in electrolyte-free water, "young" hemoglobin is a more effective buffer than "old" hemoglobin, but we were unable to demonstrate this in their respective intact erythrocytes.

We accomplished virtually complete electrolyte removal but twice measured slightly more electrolyte retention in "young" than in "old" hemoglobin solutions. This small electrolyte difference might conceivably explain the large inequality of oxygen affinity, but to do so it would have to produce a molecular difference between "young" and "old" hemoglobin. However, the electrolyte molarity is still less than one-tenth that of the minimum concentration necessary to begin to cause a decrease in oxygen affinity (increase of $\mathrm{P}_{50}$ ) with increasing electrolyte concentration. ${ }^{1}$

The change in oxygen affinity with age persists after hemolysis and virtually complete desalting by dialysis or gel filtration, but is then abolished by the subsequent addition of electrolyte. The sodium ion more rapidly effects this change than does the potassium ion. This molecular change is complete with only $18 \mathrm{hr}$ storage in $0.01 \mathrm{~m}$ sodium chloride at $4^{\circ} \mathrm{C}$. Subsequent removal of the electrolyte does not restore this difference between "young" and "old" hemoglobin.

Use of a nonelectrolyte medium has thus permitted the expression of a molecular property that could not have been expressed during or after posthemolysis exposure to an electrolyte medium. Such a molecular property, however, has developed and persisted in an intracellular medium with a high electrolyte concentration. Erythrocyte aging is known to be characterized by an increasing sodium concentration and a decreasing potassium concentration (2). We do not know what role this or other intracellular influences play in producing this change in oxygen affinity with age. "Young" and "old" hemoglobins differ because of events occurring during an interval of time in their natural in vivo intracellular environment. During this time, the cell and its primary protein exist in an intimate association. It is not possible at this time to say whether such a conformation change in hemoglobin, which pre- sumably explains this change in oxygen affinity, results from a primary alteration in its red cell environment or occurs spontaneously and independently of other intracellular changes.

The subtle change in conformation which the hemoglobin molecule apparently suffers under the in vitro extracellular influence of electrolytes may be related to allosteric phenomena $(17,18)$ or to the structure-disrupting and function-impairing effects of ions as demonstrated on enzymes, which are likewise more labile to sodium than to potassium $(19,20)$. Oxygen affinity of hemoglobin is irreversibly altered upon its first posthemolysis exposure to electrolytes. ${ }^{1}$ These observations indicate that after removal of a protein from its natural environment, subtle conformational changes may have important functional consequences even by exposures to dilute and presumably innocuous electrolytes.

It is possible that the in vitro electrolyte effect is due to screening of charged residues of the hemoglobin molecule, thus neutralizing intramolecular electrostatic interactions which by some unknown mechanism had been altered during in vivo aging. These coulombic forces have presumably stabilized the hemoglobin molecule in a changed configuration with the functional consequence of changing hemoglobin's affinity for oxygen. It is also possible that the decreased oxygen affinity and increased heme-heme interaction that we observed in the "young" erythrocytes result from their increased concentration of 2,3-diphosphoglycerate (2). This substance has recently been shown to cause such a profound decrease of oxygen affinity and increase in heme-heme interaction (18). The abolishment of the difference between "young" and "old" hemoglobin by electrolyte may be due to disruption of electrostatic bonds between the hemoglobin molecule and 2,3-diphosphoglycerate.

We do not know why these electrostatic interactions, which are postulated as influencing the oxygen affinity, are more readily influenced by the sodium ion than by the potassium ion. The sodium ion, although having a smaller atomic radius, has a larger hydrated ion radius than does the potassium ion (21). It is, therefore, improbable that steric hindrance excludes the potassium ion while allowing the sodium ion to penetrate the molecule and reach the critical points of interac- 
tion. Some other property or combination of properties must be responsible for the greater ability of sodium to lodge in the particular niche of the hemoglobin molecule where it exerts influence upon the electrostatic interaction. The fact that sodium disturbs the function of enzymes more rapidly than potassium $(19,20)$ suggests a similar in vitro mechanism in that situation. In this regard, it is interesting to note that a difference has been reported between sodium chloride and another cation, cesium chloride, in their ability to dissociate human hemoglobin into subunits (22). Specific anion effects on the oxygen affinity and heme-heme interaction have also been described (18).

X-ray diffraction studies of Muirhead and Perutz indicate that deoxygenation produces configurational changes of the hemoglobin molecule involving a $7 \mathrm{~A}$ increase between the iron atoms of the hemes of the two beta chains and the alpha ${ }_{1}$ beta $_{2}$ pair $(23,24)$. Thus, if aging results in changes in electrostatic interactions at the critical points of contact between these chains, it is conceivable that such changes would affect the interaction of hemes in determining their affinities for oxygen.

The erythrocyte presents a unique model for the study of aging. Admittedly, it is not a cell that is truly representative of all other types of cells. However, because it lacks a nucleus and other cellular organelles which provide a means for new protein synthesis, one can study the functional deterioration of its component molecules without the obscuring effect of concurrent synthesis of new protein molecules. Other proteins of other cellular systems may also deteriorate functionally with age and thus influence the physiological function of the cell, especially if there is a partial or complete failure of new protein synthesis.

\section{Acknowledgments}

We are indebted to Joanne MacAskill, Sandra Uhrhammer, and Lorna Newcombe for technical assistance and to Dr. Donald M. Pitcairn for help in preparation of the manuscript.

\section{References}

1. Allison, A. C., and G. P. Burn. 1955. Enzyme activity as a function of age in the human erythrocyte. Brit. J. Haematol. 1 : 291.
2. Bernstein, R. E. 1959. Alteration in metabolic energetics and cation transport during aging of red cells. J. Clin. Invest. 38: 1572.

3. Prankerd, T. A. J. 1961. The Red Cell : An Account of Its Chemical Physiology and Pathology. Blackwell Scientific Publications, Ltd., Oxford.

4. Edwards, M. J., R. D. Koler, D. A. Rigas, and D. M. Pitcairn. 1961. The effect of in vivo aging of normal human erythrocytes and erythrocyte macromolecules upon oxyhemoglobin dissociation. $J$. Clin. Invest. 40: 636.

5. Rigas, D. A., and R. D. Koler. 1961. Ultracentrifugal fractionation of human erythrocytes on the basis of cell age. J. Lab. Clin. Med. 58: 242.

6. Garby, L., and M. Hjelm. 1963. Ultracentrifugal fractionation of human erythrocytes with respect to cell age. Blut. 9: 284.

7. Havinga, E. 1953. Comparison of the phosphorus content, optical rotation, separation of hemes and globin, and terminal amino acid residues of normal adult human hemoglobin and sickle cell anemia hemoglobin. Proc. Natl. Acad. Sci. U. S. 39 : 59.

8. Edwards, M. J., and R. J. Martin. 1966. Mixing technique for the oxygen-hemoglobin equilibrium and Bohr effect. J. Appl. Physiol. $21: 1898$.

9. Siggaard-Andersen, O., K. Engel, K. Jorgensen, and P. Astrup. 1960. A micro method for determination of $\mathrm{pH}$, carbon dioxide tension, base excess and standard bicarbonate in capillary blood Scand. J. Clin. Lab Invest. 12: 172.

10. Perutz, M. F. 1948. Submicroscopic structure of the red cell. Nature. 161: 204.

11. Severinghaus, J. W. 1958. Oxyhemoglobin dissociation curve correction for temperature and $\mathrm{pH}$ variation in human blood. J. Appl. Physiol. 12: 485.

12. Bartels, H., K. Betke, P. Hilpert, G. Niemeyer, and K. Riegel. 1961. Die sogenannte standard- $\mathrm{O}_{2}-$ dissoziationskurve des gesunden erwachsenen menschen. Arch. Ges. Physiol. 272: 372.

13. Hill, A. V. 1910. The possible effects of the aggregation of the molecule of haemoglobin on its dissociation curves. J. Physiol. (London). 40:4P.

14. Enoki, Y., and I. Tyuma. 1964. Further studies on hemoglobin-oxygen equilibrium. Japan $J$. Physiol. 14 : 280.

15. Barcroft, J., and F. Roberts. 1909. The dissociation curve of haemoglobin. J. Physiol. (London). $39: 143$.

16. Rossi-Fanelli, A., E. Antonini, and A. Caputo. 1961. Studies on the relations between molecular and functional properties of hemoglobin. II. The effect of salts on the oxygen equilibrium of human hemoglobin. J. Biol. Chem. 236: 397.

17. Monod; J., J. P. Changeux, and F. Jacob. 1963. Allosteric proteins and cellular control systems J. Mol. Biol. 6: 306. 
18. Benesch, R., and R. E. Benesch. 1967. The effect of organic phosphates from the human erythrocyte on the allosteric properties of hemoglobin. Biochem. Biophys. Res. Commun. 26: 162.

19. Warren, J. C., L. Stowring, and M. F. Morales. 1966. The effect of structure-disrupting ions on the activity of myosin and other enzymes. J. Biol. Chem. 241 : 309.

20. Warren, J. C., and D. M. Peterson. 1966. Structure-disrupting ions: Detection of qualitative change in an enzyme. Science. 152: 1245.

21. Kachmar, J. F., and P. D. Boyer. 1953. Kinetic analysis of enzyme reactions. II. The potassium ac- tivation and calcium inhibition of pyruvic phosphoferase. J. Biol. Chem. 200: 669 .

22. Dreizen, P. 1967. Subunit interactions of human oxyhemoglobin. Abstracts of the Biophysical Society, 11th Annual Meeting. Houston, Texas. 24.

23. Muirhead, H., and M. F. Perutz. 1963. Structure of Haemoglobin: A three-dimensional Fourier synthesis of reduced human haemoglobin. at $5.5 \AA$ resolution. Nature. 199: 633.

24. Schroeder, W. A., and R. T. Jones. 1965. Some aspects of the chemistry and function of human and animal hemoglobins. Fortschr. Chem. Org. Naturstoffe. 23 : 113. 